\section{Dyrebar erfaringskunnskap}

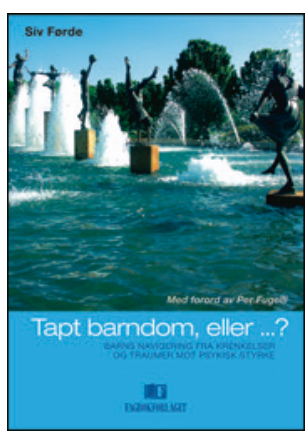

Siv Førde

Tapt barndom, eller ...?

Barns navigering fra krenkelser og traumer mot psykisk styrke. 285 s, ill. Bergen: Fagbokforlaget, 2014. Pris NOK 489 ISBN 978-82-450-1344-3

Siv Førde, psykiatrisk sykepleier og helsesøster for flyktningfamilier, og også høyskolelektor ved Høgskulen i Sogn og Fjordane, vil si noe på vegne av noen andre. Disse andre er enslige flyktningbarn som på ulike, men aldri enkle, måter har funnet veien til Norge, til landet som i manges øyne og ifølge mange målinger muligens er verdens beste å bo i og trolig verdens beste å være barn $\mathrm{i}$ - forutsatt at barnet ikke har flyktet fra krig, krise, kaos, nød eller dødsfare.

Siv Førde har arbeidet i mange år med nettopp slike barn. Hun øser av sin dyrebare erfaringskunnskap fra dette arbeidet. Den fletter hun i denne boken sammen med et vell av relevant informasjon om lover, vedtak, konvensjoner og regler, om lokale, nasjonale og internasjonale tiltak, unnlatelser og utviklinger, og med noen autentiske fortellinger om barn hun har møtt.

Hun gir kategorien flyktningbarn navn og liv: Salam, Anne og Richard er tre av dem. De var alle tre 14 år da de kom alene til Norge på flukt fra ulike kriger i Afrika, og deres vei derfra til landet i nord hadde ingenlunde vært strak. Forfatteren møtte dem i sin faglige rolle som psykiatrisk sykepleier for flyktninger og kunne derfor følge dem tett etter at de tilfeldigvis var ankommet $i$ hennes kommune.

De tre dypt traumatiserte tenåringene er bokens nav, dens omdreiningspunkt. Med dem som ankre redegjør Siv Førde for Barnekonvensjonen, Schengen-avtalen, Dublin 2-reguleringen, Ottawa-charteret og alle de andre politiske, byråkratiske og humanitære forutsetningene som enslige barneflyktninger blir møtt med, vurdert i samsvar med og behandlet etter.

Slike barn er utsatte barn. De blir ofte «borte» underveis eller fra asylmottakene ved ankomststedet. De kan bli objekter i en kullsvart global økonomi bestående av prostitusjon, barnearbeid, organsalg, krigstjenester eller illegal «adopsjon», altså salg. 106 enslige barn forsvant fra norske asylmottak mellom 2012 og 2013, uten at noen vet hvor de ble av.

Salam, Anne og Richard ble ikke borte. Med deres livsvilje, utvikling og tilpasning som eksempler og med samfunnets muligheter og tiltak som bakgrunn, beskriver Siv Førde hvordan integrering er mulig, og hvordan selv dypt skadede barn finner måter å hele sine sår på, og våger og evner å leve videre blant fremmede som de gradvis kan fatte tillit til, slik at den livsnødvendige tryggheten og selvtilliten som ble ødelagt før de kom hit, kan gjenopprettes.

Denne boken er viktig. Den er faktisk opplysende for alle fagpersoner som arbeider med barn, og da ikke bare barn som tok skade av krig og nød «der ute», men også «her hjemme». Det finnes nemlig altfor mange av dem i verdens beste land for barn.

\section{Helsepolitisk debattbok}

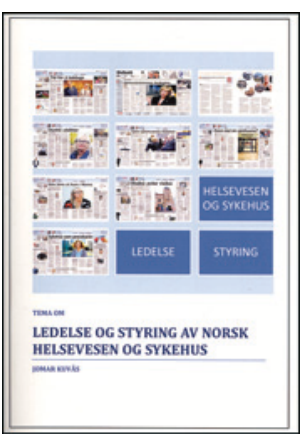

Jomar Kuvås

Tema om ledelse og styring av norsk helsevesen og sykehus

172 s, tab, ill. Eget forlag.

Pris Gratis nedlastbar

ISBN 978-82-93305-02-6

Jomar Kuvås var ansatt i ledelsen ved Rikshospitalet frem til 2009 og er nå pensjonist. De siste årene har han publisert en lang rekke debattinnlegg og artikler, som er blitt samlet mellom to permer i denne boken. Boken er gratis og kan lastes ned fra Gratisforlaget Jomar Kuvås. Forfatteren gjør innledningsvis leseren oppmerksom på at artiklene er blitt til som reaksjoner på saker, hendelser og vedtak. De 55 artiklene er gruppert i 13 kapitler, som starter med en kort oppsummerende innledning. Organiseringen er logisk, og en rekke temaer innen den helsepolitiske debatten er dekket: organisering, kvalitet, finansieringsmodeller, økonomistyring, omorganisering, fusjonsprosesser, elektroniske journalsystemer osv. Omorganiseringen av sykehusene i Oslo-området var årsaken til at Kuvås begynte å skrive debattinnlegg, og utfordringer knyttet til Oslo universitetssykehus og Helse Sør-Øst går igjen i en rekke av artiklene.

Hva er så essensen i boken? Et hovedanliggende for Kuvås er at de regionale helseforetakene har gjort jobben sin og bør avskaffes til fordel for en direkte styringslinje fra Helsedepartementet og ned til det enkelte sykehus. Rikshospitalet representerer her et historisk referansepunkt for ham. RHF-strukturen har, ifølge Kuvås, vært et «glavalag» mellom sykehusene og politisk ledelse, og den har bidratt til en uhensiktsmessig stor byråkratisering i sykehusene. Han er en sterk tilhenger av nasjonale grep der det er påkrevd, slik som innen journalsystemer og finansieringsmodeller, men er opptatt av at sykehusene må få frihet til selv å utvikle virksomhetene innenfor gitte rammer. Han mener innsatsstyrt finansiering er en uheldig modell, og foreslår rammefinansiering med tydeligere krav og føringer, der systemet kompenserer sykehus som har de krevende pasientene. Han ønsker å styrke virksomhetenes egen mulighet til økonomistyring gjennom å innføre et system med beregning av kostnad per pasient (KPP). Han peker på ventelistene og køene, og mener helsesektoren må tilføres mer ressurser.

Det er sykehusdrift som får oppmerksomhet i boken, mens primærhelsetjenesten knapt er nevnt. Analysene går sjelden i dybden, noe som heller ikke er mulig innenfor debattformatet, men jeg savner noen flere referanser til utviklingstrender i andre land. I Norge kan vi bli noe navlebeskuende og innbille oss at vi er alene om å ha utfordringer i helsevesenet - slik er det ikke. Dette er en bok som presenterer ett perspektiv på de mange utfordringene i helsevesenet. Den er verd å lese - som et innlegg i den pågående helsepolitiske debatten.

\section{Jan Frich}

Professor, Institutt for helse og samfunn Universitetet i Oslo 